\title{
GOOD HYGIENE PRACTICES IN THE RECOVERY FOOD SUPPLY CHAIN: CASE STUDY AND GRADING SYSTEM APPLICATION FOR CHARITABLE ORGANIZATIONS
}

\author{
UDC 613.26:614.2:35.078.3
}

\author{
Marta Castrica ${ }^{1}$, Sabrina Ratti ${ }^{1}$, Vesna Milicevic ${ }^{2}$, \\ Giampaolo Colavita ${ }^{3}$, F. Ranghetti ${ }^{1}$, Marko Lucchini ${ }^{4}$, \\ Giuliana Malaguti ${ }^{4}$, Claudia M. Balzaretti ${ }^{1}$ \\ ${ }^{1}$ Department of Health, Animal Science and Food Safety (VESPA), \\ Università degli Studi di Milano, Milan, Italy \\ ${ }^{2}$ Health Protection Agency, Metropolitan City of Milan, Milan, Italy \\ ${ }^{3}$ Department of Medicine and Health Science "Vincenzo Tiberio", \\ University of Molise, Campobasso, Italy \\ ${ }^{4}$ Fondazione Banco Alimentare Onlus, Milan, Italy
}

\begin{abstract}
The no profit organizations manage food under the respect of the EU food safety rules. The EU food safety legislation provides the application of simplified procedures considering the level of complexity of each charitable organization (COs) and encourages the elaboration of Good Hygiene Practices Manuals (GHP) according to Regulation (EC) No. 852/2004. Recently, a study conducted by the working group of the Department of Health, Animal Science and Food Safety (University of Milan), has focused on the application of a new inspection-scoring model based on the use of a checklist. Checklist was elaborated taking into account the Manual of good practices for COs, validated by the Italian Ministry of Health. The aim of the checklist has been to verify the suitability to the sanitary hygiene requirements of the COs. (The GHP manual is available at http://cdn. bancoalimentare.it/sites/bancoalimentare.it/files/manualecaritasbanco_eng_007.pdf
\end{abstract}

Key words: Food Bank, food recovery, hygiene practices, inspection score

\section{INTRODUCTION}

Food is a basic human right, together with water, education, peace, and health care (McIntyre, 2003). In the EU, close to one-quarter of the population (119.1 million people)

Received January 10, 2018 / Accepted January 19, 2018

Corresponding author: Sabrina Ratti

Department of Health, Animal Science and Food Safety (VESPA), Università degli Studi di Milano, Italy

E-mail: sabrina.ratti@unimi.it 
were at risk of poverty or social exclusion in 2015 (FUSIONS, 2016). At the same time, it is estimated that around 88 million tons of food waste are generated annually in the EU (FUSIONS, 2016).

In this context, food banks could be the key to reducing famine by decreasing the sources of food waste (Vittuari et al, 2017). The non-profit organizations not only reduce the amount of surplus food but also can be an effective system in order to support the fight against food poverty and promotes social inclusion (Rovati et al, 2015). Therefore, since the 1960, charitable organizations have arisen worldwide and their aim was to transform a paradox in a social assets.

The first food bank was created in 1966 in Phoenix, Arizona, USA, the St. Mary's Food Bank that laid the groundwork for the development of Feeding America. Instead, in Europe, in 2016, European Federation of Food Banks (FEBA) distributed 535.000 tons of food to 6.1 million people (FEBA, 2016). In Italy, the two most important examples of COs are Caritas Italiana and Fondazione Banco Alimentare ONLUS (FBAO) that together cover 70 percent of the food donations. The activity of a food bank depends on its suppliers (food companies and other donators), and it has effect on the quantity and nutritional quality of food recovered. Actually, the food banks act as a wholesaler, although are bound by the availability of the food supplies donated, precisely the opposite of a conventional supply chain (Gonzalez-Torre et al, 2015).

In order to protect the consumers and ensure food safety, the charitable organizations manage food under the respect of the general hygiene requirements established by the European rules. The food banks, such as food business operators, must comply with the General Food Law and with Regulations (EC) No 852/2004 (EC, 2004) containing general hygiene requirements. In Italy, there are also the Manual of good practices for COs (Caritas Italiana \& Fondazione Banco Alimentare Onlus, 2015), validated by the Italian Ministry of Health in 2015, the Law No 155/2003 called "Legge del Buon Samaritano" and the Law No 166/16 called "Legge Gadda" (Italian Parliament, 2016). Moreover, in 2017 the European Commission has released a notice concerning guidelines on food donations in order to clarify relevant provisions in EU legislation and help lift barriers to food redistribution within the current EU regulatory framework (EU, 2017).

Actually, in Italy, there is no standard method to evaluate the hygiene practices adopted by food banks in order to compare different situations and to improve the efficiency and the growth of the donations system. For this reason, the development of an experimental method (checklist) for the application a grading system in Italy represents a useful model for the external auditors and an easy-to-use tool for the food bank volunteers.

The checklist was elaborated considering the guidelines drawn up by authors for the inspections of food services in Lombardy and the guidelines drafted by NYC Department of Food Safety and Mental Hygiene (City of New York-Department of Health and Mental Hygiene, 2007).

Since 1932 (McDean, 1997), the inspection checklist have evolved all over the word as a valid tool used by the competent authorities during the inspections in public commercial establishments. Actually, in various fields grading systems they are used to disclose the inspection results to the final consumers.

The aim of this study was to elaborate, starting from two charitable organizations selected from the head office, a checklist with an inspection score and grading, in order to assess the compliance with sanitary hygiene requirements of food banks and to make the 
results available to the members of the network. Finally, the checklist can represent a valuable system of self-testing and for food bank volunteers.

For the first time in this study, the checklist was used to evaluate Cos. This tool is easier than the model previously elaborated, because it takes into account the simplified and specific reality of non-profit organizations. Furthermore, the checklist based on the European food safety legislation, the Manual of good practices for charitable organizations (Caritas Italiana \& Fondazione Banco Alimentare Onlus, 2015), and the EU food donation guidelines (EU, 2017).

\section{MATERIALS AND METHODS}

\subsection{Data collection}

The preliminary study involved only two food banks (hereafter CO1 and CO2) linked to the same network and located in two different Northern Italian regions. The food banks were selected for various reasons including territorial, organizational and operating differences. Data collection was carried out in May and June 2017 through several on-site inspections for both food banks. In each food bank, information was collected in order to evaluate quality and logistics manager, members involved, volunteers, premises and equipment, vehicles, foodstuff beneficiaries, food supply system, supply channels and food quantities. During the on-site inspections, in order to evaluate health and hygiene aspects, the checklist with a scoring system was applied.

\subsection{Structure of the checklist}

The authors developed a specific checklist considering the background and the specificity of the food banks. The checklist may be defined as a "simplified checklist", as compared to the checklist elaborated for public establishments. The checklist was subdivided into 10 sections; each section represents a prerequisite to be verified during the on-site inspection. Table 1 provides the list of all sections described in the checklist.

Table 1 Checklist structure.

\begin{tabular}{lcc}
\hline Section & Item & Number of subsections \\
\hline Section 1 & Administrative parameters and HACCP & 7 \\
Section 2 & Temperature management & 2 \\
Section 3 & Food supply system and acceptability of foodstuffs & 6 \\
Section 4 & Locals and equipment & 5 \\
Section 5 & Hygiene of food handling activities & 7 \\
Section 6 & Transport management & 4 \\
Section 7 & Waste management & 4 \\
Section 8 & Food operators training & 2 \\
Section 9 & Food handlers hygiene & 4 \\
Section 10 & Cleaning and sanitation procedures & 6 \\
\hline
\end{tabular}

Each section was further subdivided into a different number of subsections called procedural compliance that are to be verified through on-site observation. 
To each procedural compliance (subsections) corresponds: (i) three evaluation classes that was assigned different violation points. The first class called "complete compliance" suggests a total compliance with the requirements, the second class represents a "partial compliance" and the third one relates to a situation of "non-compliance". In addition to_each subsections corresponds: (ii) the type of the violation, which may be critical or general.

\subsection{Definition of score}

During the on-site inspection, the determination of the score depended on the number and severity of the violations. Each evaluation class corresponds to a baseline violation score: (i) score class one: assignment of zero violation points, (ii) score class two: assignment of 5 violation points and (iii) score class three: assignment of 10 violation points.

As regards the type of the violation, the observance of some subsections is of greater importance than others. For this reason, when the violation is critical, a score of 2 is added to the baseline score obtained in the respective subsections; instead of general violation where 1 point is assigned.

Subsequently, a grading was assigned in relation to the final score (Table 2), the demerit points-based system was scored on a 100 point scale.

Table 2 Demerit points scoring.

\begin{tabular}{cccc}
\hline Score & Grading & Condition & Compliance \\
\hline $0-30$ & A & Good & Complete \\
$31-70$ & B & Need Improvement & Partial \\
$\geq 71$ & C & Poor & Non-compliance \\
\hline
\end{tabular}

The assignment of letter A was reserved to food banks which generally have had minor or no non-compliance (accordance with the requirement), while letter B was reserved to food banks, which have not completely respected the procedures. Finally, letter $\mathrm{C}$ was assigned to food banks that had a stringent non-compliance and where there was a risk for the final consumer (poor people).

\section{RESULTS AND DISCUSSION}

From the collected data, it is possible to reveal some differences between the two investigated food banks. Considering the different geographic area in which the food banks operate, the main evidence is related to the premises and equipment, showed in Figure 1. 


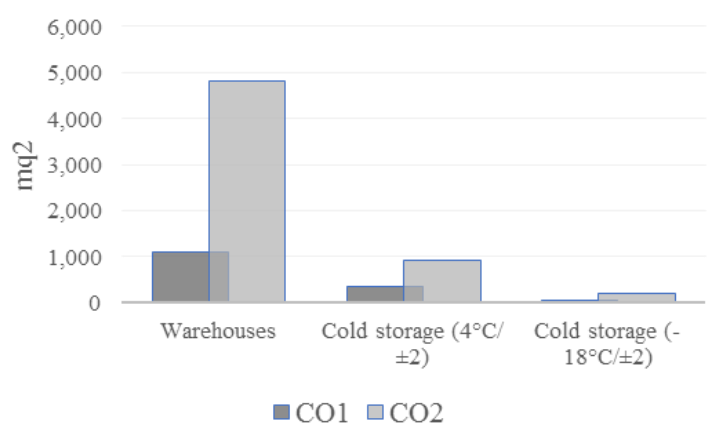

Fig. 1 Premises and equipment results.

Those differences are directly linked to other some parameters as the number of operators, beneficiary structures and the total amount of foodstuffs distributed (Figure 2).

$\mathbf{a}$

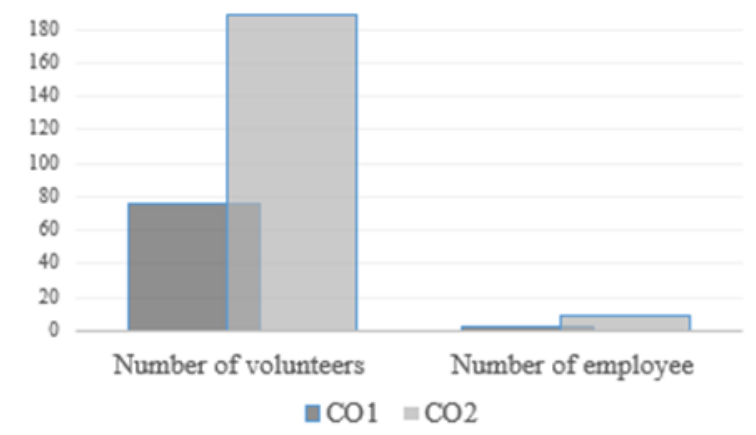

b

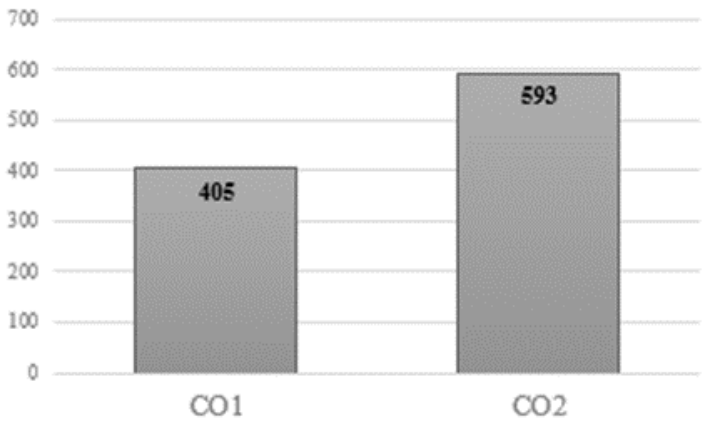




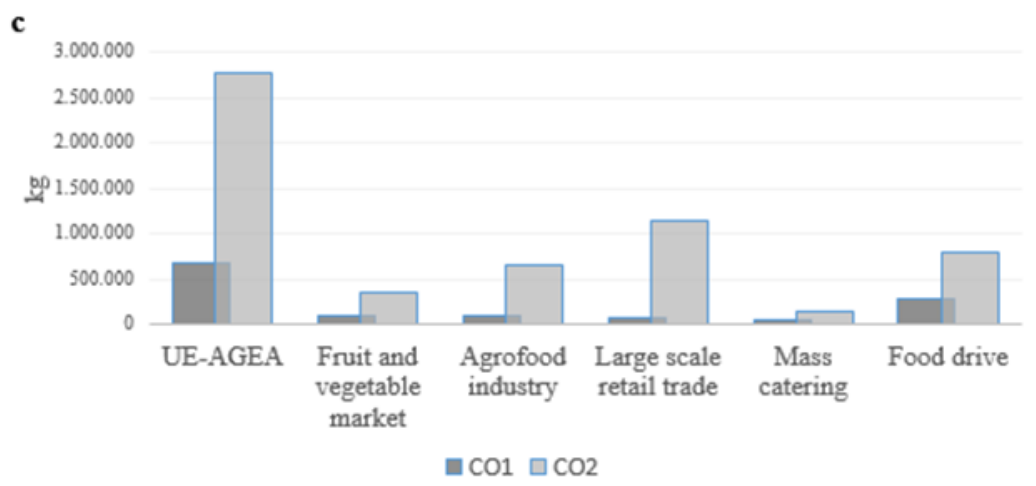

Fig. 2 (a) Number of volunteers and employee (b) beneficiary structure and (c) foodstuffs distributed.

Moreover, it is important to notice that for the $\mathrm{CO} 1$ the $54.7 \%$ of incoming products donated were from Agenzia per le Erogazione in Agricoltura (AGEA) channel, the European program for the most deprived. The incoming products are mainly non -perishable and packaged.

For the CO2, AGEA represents only the $43.3 \%$ of the incoming products. This food bank is trying to develop a conduit of collecting perishable food, such as fruits and vegetables, in order to guarantee an elevated nutritional standard and to assure food donation for humans in need, respecting the sanitary hygiene criteria.

The results obtained from the checklist confirm the differences between the COs. The CO1 was classified with $\mathrm{C}$ (checklist score $=112$ ), in particular, the application of the Good Hygiene Practices Manual (GHP) for charitable organizations appears to be imprecise and incomplete. The main non-compliances are connected to the HACCP system and volunteers training. The $\mathrm{CO} 2$ was classified with $\mathrm{A}$ (checklist score $=26$ ), the non-compliances observed were not serious and/or dangerous.

The results obtained, have proved the sustainability of the checklist use in other field, such as food banks. Moreover, other authors confirm the importance of this tool to evaluate the food service establishments (Razzini \& Balzaretti, 2015; Da Cunha et al, 2016). The food banks fit into this context because they must respect the food safety EU legislation, and for this reason are subject to controls by the external auditors and competent authorities (Milicevic et al, 2016).

In the third sector, it is fundamental to consider the context of the food bank activities and related limits (for example the prevalence of non-specialized volunteers). In fact, other studies (Emmanuel et al., 1995) have demonstrated that the grading system is an easy and direct method to evaluate the establishments and for this reason has proved useful for the food banks evaluation. Moreover, the inspection score model allows a preventive approach in identifying potential risks, as observed in other study conducted in different places (Buchhloz et al., 2002; Da Cunha et al., 2014; Zablotsky Kufel et al., 2011). The checklist application could be useful as a self-management procedure for the volunteers (Caritas Italiana \& Fondazione Banco Alimentare Onlus, 2015). 
It must be emphasized that the evaluation of each food bank shall be performed taking into account its level of organization in terms of: different types of food managed, different frequency of distribution, high turnover of volunteers and different beneficiaries (Caritas Italiana \& Fondazione Banco Alimentare Onlus, 2015).

\section{CONCLUSION}

In conclusion, the creation of a database could be possible for each food bank. This could also help the management of problems and ameliorate the efficiency of the entire system, in order to increase the quantities and different types of incoming foodstuffs.

\section{REFERENCES}

1. McIntyre; L; Food security: more than a determinant of health, Options Politiques; pp. 46-51; 2003

2. FUSIONS; Estimates of European food waste levels; March 2016.

3. Vittuari; M; De Menna; F; Gaiani; S; Falasconi; L; Politano; A; Dietershagen; J; Segrè; A; (2017). The Second Life of Food: An Assessment of the Social Impact of Food Redistribution Activities in Emilia Romagna, Italy, Sustainability; 9 (10), 1817; 2017.

4. Rovati; G; Pesenti; L; Food poverty, food bank, Vita e pensiero; Milan, Italy; 2015.

5. European Federation of Food Banks (FEBA): http://www.eurofoodbank.eu/.

6. González-Torre; PL; Coque; J; How is a food bank managed? Different profiles in Spain, Agriculture and Human Values: volume 33, Issue 1; pp. 89-100; 2016.

7. European Commission; Regulation of the European Parliament and of the Council of 29 April 2004 on the hygiene of foodstuffs 852/2004/CE. In Official Journal, L 139/1, 30/4/2004.

8. Caritas Italiana; Fondazione Banco Alimentare Onlus; Manual of Good Practices for Charitable Organisations; 2015

9. Italian Parliament; LEGGE 19 Agosto 2016, n. 166 Disposizioni concernenti la donazione e la distribuzione di prodotti alimentari e farmaceutici a fini di solidarietà sociale e per la limitazione degli sprechi, Italian Parliament; Rome; Italy; 2016.

10. European Commision; EU Food Donation Guidelines; 16 October 2017

11. City of New York - Department of Health Mental Hygiene; Inspection Scoring System for Food Service Establishments; New York, NY: Departament of Health and Mental Hygiene; 2007.

12. McDean; HC; Dairy products, Whitten DO, Whitten BE, eds. Handbook of America Business history: extractives, manufacturing and service. Greenwood Publishing Group, Westport, CT, USA; pp 141-160; 1997.

13. Razzini; K; Balzaretti; CM; Premise to implement a grading system to evaluate the sanitary level in food service establishments in Milan, Italy, Italian Journal of Food Safety 4:4514; pp 145-151; 2015.

14. Da Cunha; DT; De Freitas Saccol; AL; Tondo; EC; De Oliveira; AB; Ginani; VC; Araújo; CV; Stedefeldt; E; Inspection score and grading system for food services in Brazil: the results of a food safety strategy to reduce the risk of foodborne diseases during the 2014 FIFA World Cup, Frontiers in microbiology 7; pp 1-10; 2016.

15. Milicevic; V; Colavita; G; Castrica; M; Ratti; S; Baldi; A; Balzaretti; CM; Risk assessment in the recovery of food for social solidarity purposes: preliminary data, Italian journal of food safety; 5(4); 2016.

16. Emmanuel; BP: Grading a food establishment, Journal of Environmental Health 58, Issue 3; 1995.

17. Buchholz; U; Run; G; Kool; JL; Fielding; J; Mascola; L; A risk-based restaurant inspection system in Los Angeles County, Journal of Food Protection 65; pp 367-372; 2002.

18. Da Cunha; DT; De Oliveira; ABA; De Freitas Saccol; AL; Tondo; EC; Silva; EA; Jr Ginani; VC; Food safety of food services within the destinations of the 2014 FIFA World Cup in Brazil: Development and reliability assessment of the official evaluation instrument, Food Res 57; pp 95-103; 2014.

19. Zablotsky Kufel; JS; Resnick; BA; Fox; MA; McGready; J; Yager; JP; Burke; TA; The impact of local environmental health capacity on foodborne illness morbidity in Maryland, American journal of public health 101(8); pp 1495-1500; 2011. 


\section{DOBRA HIGIJENSKA PRAKSA U LANCU SNABDEVANJA ZA PREOSTALU HRANU: STUDIJA SLUČAJA I PRIMENA SISTEMA OCENJIVANJA ZA HUMANITARNE ORGANIZACIJE}

Neprofitne organizacije upravljaju hranom u skladu sa pravilima EU o bezbednosti hrane. Zakonodavstvo EU o bezbednosti hrane reguliše jednostavne procedure uzimajući u obzir nivo složenosti humanitarnih organizacija (eng.charity organizations -COs) i predstavlja okvir za izradu Priručnika dobre higijenske prakse (eng. Good Hygienic Practice - GHP) prema Regulativi (EC) br. 852/2004. Fokus nedavnog istraživanja koje je sprovela radna grupa sa Departmana za zdravlje, veterinarstrvo $i$ bezbednost hrane (Univerzitet $u$ Milanu) je primena novog modela inspekcijskog pregleda zasnovanog na korištenju kontrolne liste. Kontrolna lista je elaborirana imajući u vidu Priručnik dobre prakse za COs, prihvaćen od strane Italijanskog Ministarstva za zdravlje. Cilj kontrolne liste je bio da se verifikuje pogodnost potreba sanitarne higijene zaCOs. (Priručnik GHP je dostupan na sledećoj adresi: http://cdn.bancoalimentare.it/sites/ bancoalimentare.it/files/manualecaritasbanco_eng_007.pdf

Ključne reči: Banka Hrane, preostala hrana, higijenske prakse, rezultati inspekcije 